\title{
O JAKUBIE KARPIŃSKIM PRYWATNIE I PUBLICZNIE
}

Mirosława Grabowska

Uniwersytet Warszawski

Poznałam Jakuba Karpińskiego zimą 1967/68 roku, gdy rozpoczęłam studia na Wydziale Filozofii na kierunku socjologia. Jakub zaproponował wtedy grupce pierwszoroczniaków stworzenie nieformalnej grupy dyskusyjnej. Oczywiście wszyscy czuliśmy się z tego powodu bardzo wyróżnieni. Spotykaliśmy się na pierwszym piętrze w kawiarni „Telimena” przy okrągłym stole, w kłębach dymu papierosowego. Czytaliśmy, dyskutowaliśmy. Dzisiaj powiedziałabym, że Jakub w trakcie rozmowy stosował metodę sokratejska - poprzez zadawanie pytań, konfrontowanie wypowiedzi - usiłował wydobyć $z$ nas porządne myślenie, ważące argumenty. Ale dla nas najbardziej liczyło się to, że znany asystent (takie wtedy zajmował stanowisko) chce się z nami spotykać i z nami rozmawiać. Chyba wtedy po raz pierwszy doświadczyliśmy takiej ważnej cechy dla całej mojej późniejszej znajomości z Jakubem: był bardzo otwarty i życzliwy w stosunku do ludzi, a jednocześnie - merytoryczny, w tym sensie, że głupstwom nie odpuszczał.

Kolejne wspomnienie to już są czasy po proteście konstytucyjnym w 1975 roku. Jakub od wyjścia z więzienia w 1971 roku nie pracował „na etacie”. Ja właśnie przestałam pracować po proteście konstytucyjnym. Ale spotykaliśmy się na seminarium Stefana Nowaka, który starał się utrzymać nas przy nauce. My, trochę młodsi od Jakuba, przeżywaliśmy różne fascynacje, byliśmy w kontrze do pozytywistycznej tradycji Zakładu Metodologii, w pewnej też kontrze do samego Stefana Nowaka. Pamiętam swój referat pełen fascynacji hermeneutyka, który Jakub najpierw bardzo solidnie skrytykował, a potem żartobliwie spuentował: „hermenautyka, czyli pływamy, pływamy”. I ten komentarz zapamiętałam może nawet lepiej niż te solidne argumenty wytoczone przeciwko. Widać było w tej puencie Jakuba jako nieodrodnego, dowcipnego adepta szkoły lwowsko-warszawskiej. 
Od 1978 roku Jakub był za granica. Zobaczyliśmy się dopiero po jedenastu latach, jesienią 1989 roku w Paryżu. Ale tych lat jakby nie było. Czekałam na niego na którejś stacji metra. Jakub, oczywiście, się spóźnił, ponieważ Jakub się spóźniał. Dla niego każda tocząca się rozmowa była najważniejsza, ważniejsza niż te później umówione (które dopiero miały stać się najważniejsze). Tłumaczył mi, że spotykał się z pewnym socjologiem. Ja z kolei wyzłośliwiałam się, że przedkładał członka Rady Konsultacyjnej przy Przewodniczącym Rady Państwa, którym wtedy był generał Jaruzelski, nad spotkanie ze mną. On na to, że Rada Konsultacyjna nie była wiele gorsza od Okragłego Stołu. No i tak od słowa do słowa, już w trzecim zdaniu pokłóciliśmy się o okragłostołowy kompromis. Jakub bardzo go krytykował (jako kompromis „zgniły”, spowalniający „przechodzenie do demokracji”), a ja zażarcie broniłam (jako optymalne „wychodzenie z komunizmu”). Ale kłótnie z Jakubem nie bolały, nie upokarzały. Po dłuższej wymianie argumentów (historycznych, politologicznych i moralnych) każde $z$ nas pozostało przy swoim. On przy krytycznym stanowisku wobec Okragłego Stołu - przypominam, że to była jesień 1989 roku - a ja przy entuzjastycznym. I w pełnej komitywie poszliśmy na lody, na Wyspę Świętego Ludwika, i do polskiej księgarni. Jednak choć wtedy pozostałam „przy swoim" i do dziś sądzę, że było to niezłe wyjście z komunizmu, to jego argumenty zapadły mi w pamięć i mogłabym je dzisiaj powtórzyć.

W 1997 roku, po prawie dwudziestu latach od wyjazdu z Polski i po trzydziestu latach od opuszczenia uniwersytetu, Jakub wrócił do Zakładu Metodologii, do Instytutu Socjologii, na Wydział, na stanowisko zwykłego adiunkta. Był zupełnie odporny na hierarchie, na zaszczyty. Obchodzili go ludzie i sprawy, a nie rangi i pawie pióra. Studenci go uwielbiali. Jego zajęcia były oblegane. (Trochę mu zazdrościliśmy.) Jakub był cały wychylony w kierunku studentów: bardzo ich szanował, lubił, pamiętał o nich. $\mathrm{Na}$ kilka dni przed śmiercią zadzwonił do mnie, żeby mi tłumaczyć, jaka jest sytuacja jego studentów, komu trzeba zaliczyć, kim trzeba się zająć i jak trzeba się zająć jego magistrantami. Wszystko wnikliwie omówiliśmy, a ja - choć wiedziałam, jak poważnie jest chory - nie miałam świadomości, że Jakub już wtedy umierał. Po trzech dniach nie żył. I to była nasza ostatnia rozmowa poświęcona temu, jak należy się zaopiekować jego studentami.

Teraz o Jakubie publicznie. Jakub nie tylko pisał - można powiedzieć, że był pisarzem opozycji. Nie powinno to dziwić, dlatego że pisał niezwykle jasno, logicznie, w uporządkowany sposób i zawsze trafiał w sedno. Ale chyba nie uświadamiamy sobie, że to się odbywało tak systematycznie, na taką skalę. Przypomnę tylko najsłynniejsze dokumenty, nad którymi on, 
jako współautor i redaktor, pracował. Były to Deklaracja Ruchu Studenckiego z marca '68, List 59' , mniej znany List 142', solidaryzujący się z robotnikami w 1976 roku; Deklaracja Ruchu Demokratycznego z 1977 roku, nad która pracował razem z Jackiem Kuroniem. W ogóle dużo pracował nad dokumentami KOR-owskimi i w związku z tym dużo pracował z Jackiem Kuroniem. Pisał ważne teksty do „Głosu”’3. W czasie, kiedy jeszcze był w Polsce, spotykał się z SKS-em ${ }^{4}$, działał w TKM-ie ${ }^{5}$. To wszystko było niejako naturalne, ponieważ miał prawdziwą pasję dydaktyczna, w sokratejskim tego słowa znaczeniu, a nie w nauczycielsko-belferskim.

Będąc za granica, był w gruncie rzeczy w Polsce, o czym najlepiej świadcza jego prace, jego książki i jego działalność.

Wydaje mi się, że nie należał do żadnej epoki. Oczywiście nie należał do PRL-u. Był znakomicie wyedukowany, nieposłuszny w myśleniu i wewnętrznie zupełnie wolny. Ale nie był też „przedwojenny”. Choć pełen kultury i wdzięku przedwojennych salonów warszawskich (jak je sobie wyobrażam), to zarazem niesłychanie egalitarny, demokratyczny. Egalitarnie traktował swoich rozmówców i rozmawiał właściwie ze wszystkimi jak równy z równym. A nie wszyscy byli mu równi. Daleko nie wszyscy. Nie jestem pewna, jak odnalazłby się w dzisiejszej III Rzeczypospolitej. Był skromny i nigdy nie miał parcia na uznanie, na zaszczyty. Myślę, że miał świadomość własnej wartości i te zaszczyty nie były mu do niczego potrzebne. Czy jest dziś taki człowiek, który potrafiłby współpracować i z kimś takim jak Jacek Kuroń, i z kimś takim jak Antoni Macierewicz? Wattpię.

Chciałabym zakończyć optymistycznie. Wydaje mi się, że po powrocie na uniwersytet Jakub łatwo się na nim odnalazł, dobrze się tu czuł, właściwie wrócił do swojego żywiołu. Mam nadzieję, że do swojego matecznika.

\footnotetext{
${ }^{1}$ List 59 został napisany i zredagowany przez Jana Olszewskiego, jego pomysłodawcę, oraz Jakuba Karpińskiego i Jacka Kuronia. Był podpisywany na przełomie roku 1975 i 1976. Sygnatariusze tego listu, na początku pięćdziesiąt dziewięć osób (stąd nazwa) - twórcy, intelektualiści, działacze protestowali przeciwko zmianom w Konstytucji PRL, zwłaszcza wpisaniu do niej kierowniczej roli PZPR i wieczystego sojuszu z ZSRR.

${ }^{2}$ List 14 powstał z inicjatywy Jana Olszewskiego, który napisał go z Jakubem Karpińskim. Stanowił protest przeciwko drastycznym represjom stosowanym wobec uczestników wydarzeń czerwca 1976 roku.

3 „Głos” to wydawane w podziemiu (w latach 1977-1981) pismo opozycji demokratycznej, związane z Komitetem Samoobrony Społecznej „KOR”. Na początku współredagowane przez Antoniego Macierewicza oraz Adama Michnika, który w wyniku konfliktu w redakcji odszedł i założył „Krytykę".

${ }^{4}$ SKS - Studencki Komitet Solidarności.

5 TKM - Towarzystwo Kursów Naukowych.
} 